\title{
Optimization of Nipa Sap Preparation for Ethanol Production
}

\author{
Sirinun Puangpee* and Sininart Chongkhong \\ Department of Chemical Engineering, Faculty of Engineering, Prince of Songkla University \\ ${ }^{*}$ Corresponding author
}

\begin{abstract}
Nipa sap is one of the efficient feedstocks for ethanol production. Response surface methodology with the central composite design was used to design and optimize the sap preparation. The main factors were initial $\mathrm{pH}(4.5$ - 6.5), warming temperature $\left(30-60^{\circ} \mathrm{C}\right)$ and time $(5-30 \mathrm{~min})$. The effects of the sap preparation on the content of total sugar were studied providing the high determination coefficient, $R^{2}=0.942$. The optimum total sugar, $411 \mathrm{~g} / \mathrm{L}$, was obtained at an initial $\mathrm{pH}$ of 4.9 and at a temperature of $54^{\circ} \mathrm{C}$ for $25 \mathrm{~min}$.
\end{abstract}

\section{Keywords-nipa sap; pretreatment; total sugar; ethanol}

\section{INTRODUCTION}

Ethanol, renewable energy, can be produced from a biomass that is classified into three types. There are sugar, starch and cellulose materials used as feedstock for ethanol production with different process. The steps for transferring to ethanol of sugar material are less than the others [1-4]. The only required step is to prepare sugars sufficient before fermentation. Currently the major feedstocks for the ethanol production in Thailand are sugarcane and cassava which are relative to consumption and are used for many other products. One of the interesting choices of sugar material is nipa sap. Nipa sap is collected by tapping the stalk daily to obtain its sugar sap. Tapping results have no residual waste and have not deleterious effect on the nipa palm growth [5]. While the extraction of sugarcane juice remains some residue. Nipa palm can provide 20 ton of nipa sap / ha that can be converted to $14,300 \mathrm{~L}$ of ethanol / ha. It is more than twice as much sugarcane juice. Moreover the sap composes high content of fermentable sugars and nutrients. These caused the sugar are readily decomposed by microorganisms. Thus the sugars are pretreated suitably by dilution to an adequate sugar concentration, warming and adjustment of $\mathrm{pH}$.

This work is purposed to determine the optimal conditions (pH, heating temperature and time) for the nipa sap preparation by response surface methodology (RSM) used widely to evaluate the effective condition [6-8].

\section{MATERIALS AND METHODS}

\section{A. Materials}

Sap of Nipa (Nypa fruticans) was obtained from nipa palm plantation in Pak Phanang, Nakhon Si Thammarat province. The components of the nipa sap are shown in Table 1.
TABLE I. THE COMPONENTS OF NIPA SAP

\begin{tabular}{lc}
\hline Component & Nipa sap \\
\hline Total sugar & $369.7 \mathrm{~g} / \mathrm{L}$ \\
Reducing sugar & $25.94 \mathrm{~g} / \mathrm{L}$ \\
Moisture content & $84.96 \% \mathrm{w}$ \\
pH & 5.57 \\
Density & $1070.8 \mathrm{~kg} / \mathrm{m}^{3}$ \\
Acetic acid & $0.041 \mathrm{~mol} / \mathrm{L}$ \\
Ethanol & $2.36 \% \mathrm{v}$ \\
Yeast & $7.0 \times 10^{4} \mathrm{CFU} / \mathrm{ml}$ \\
\hline
\end{tabular}

\section{B. Nipa sap Preparation}

The nipa sap was filtered through a fabric filter to remove an impurity solid. The $\mathrm{pH}$ of the sap was adjusted to be 4.5-6.5. The bottles were immersed in an oil bath under controlled temperatures of $30-60{ }^{\circ} \mathrm{C}$ for studied time of 5-30 min. After that total sugar content in the pretreated sap was analyzed by UV-Visible spectrophotometer (UV).

\section{Analytical Method}

The total sugar was determined by modified phenol sulfuric method [9] using a double beam UV-Visible spectrophotometer (model HP 8453) with Chem Station software at $490 \mathrm{~nm}$.

\section{RESULTS AND DISCUSSION}

\section{A. Effect of Preparation on Total Sugar Yield}

The effects of $\mathrm{pH}$ and temperature on total sugar for 18 min are shown in Figure 1. The total sugar content in the pretreated product increased with an increase in temperature for all $\mathrm{pH}$ value. The highest optimum content (400-467 g/L) was achieved at $53-60{ }^{\circ} \mathrm{C}$.

Effects of $\mathrm{pH}$ and time on total sugar at $45^{\circ} \mathrm{C}$ are shown in Figure 2. The total sugar content decreased when the $\mathrm{pH}$ value increased. But the total sugar content increased when the time increased. The showed that the preparation could be operated at acidity with $\mathrm{pH}$ of $4.5-4.6$ for $25-30$ min providing 311-356 $\mathrm{g} / \mathrm{L}$ of total sugar content. 

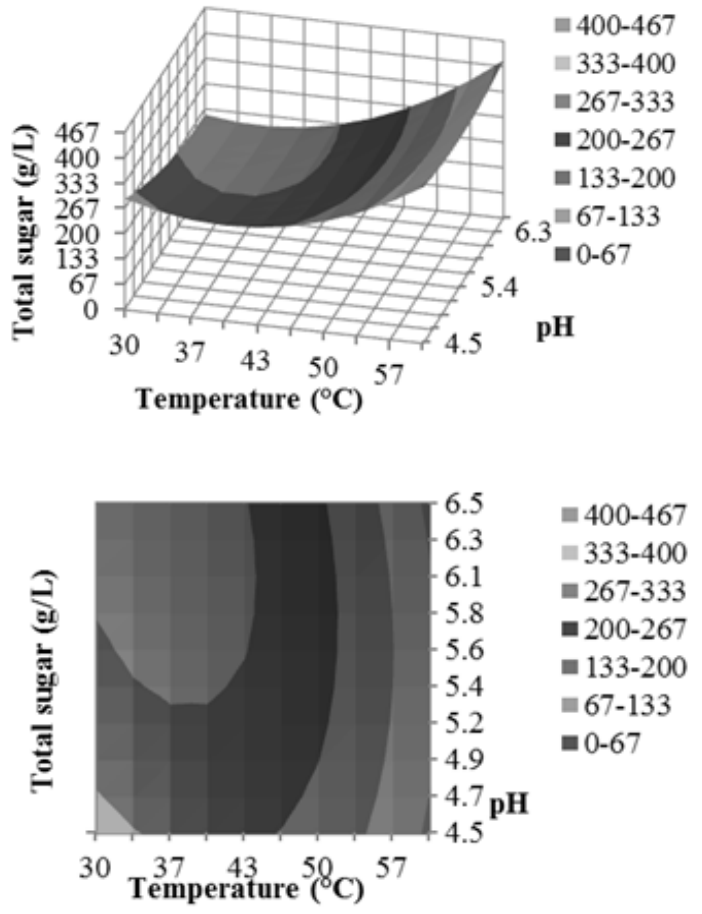

FIGURE I. Response surface and contour plot showing the effects of temperature and initial $\mathrm{pH}$ on the total sugar content with pretreatment time $18 \mathrm{~min}$
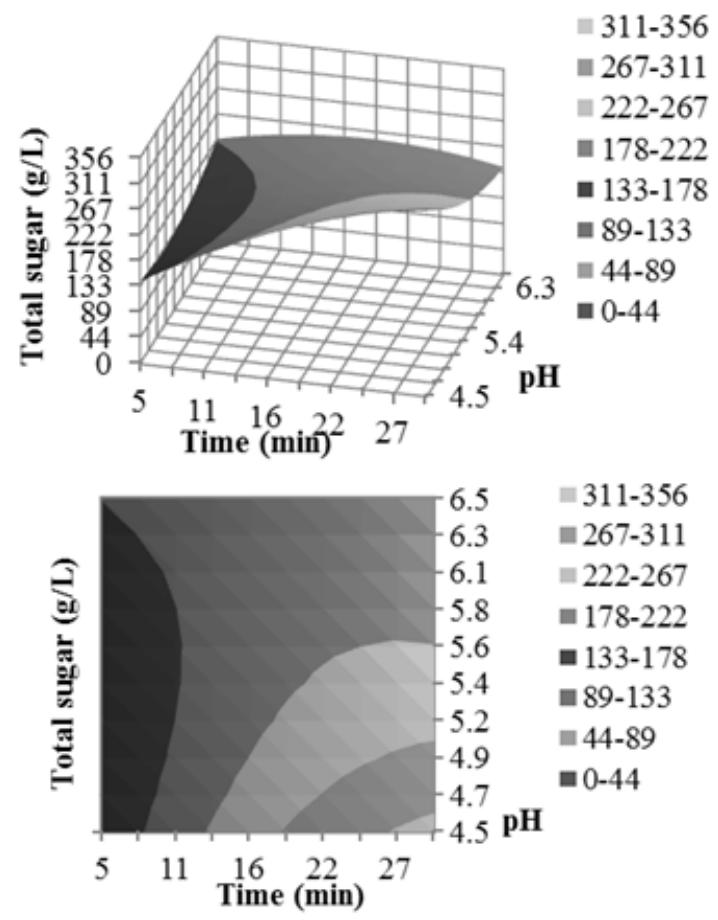

FIGURE II. RESPONSE SURFACE AND CONTOUR PLOT SHOWING THE EFFECTS OF INITIAL PH AND PRETREATMENT TIME ON THE TOTAL SUGAR CONTENT WITH HEAT TREATMENT AT $45^{\circ} \mathrm{C}$
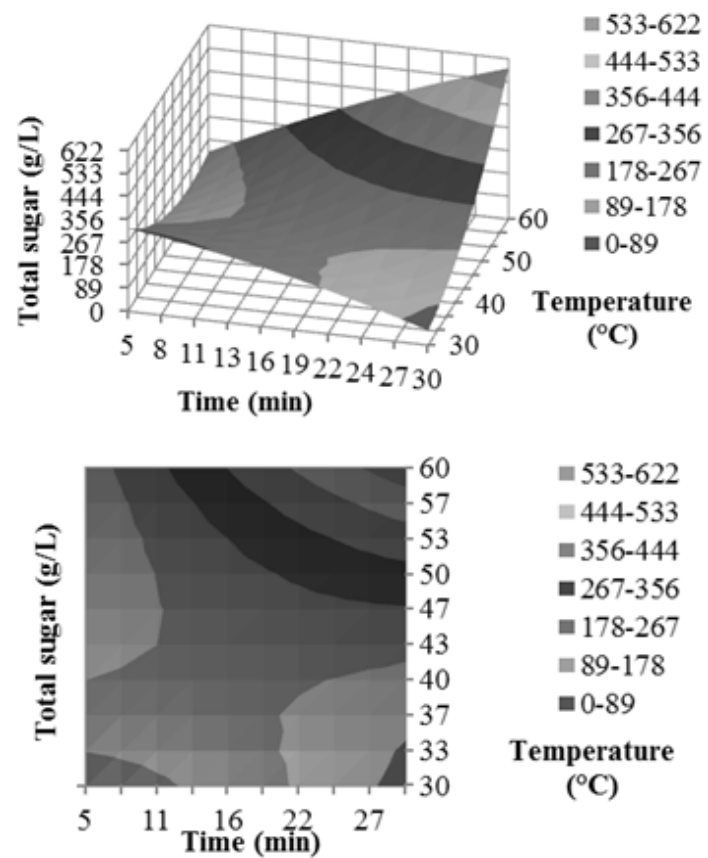

$=533-622$

$=444-533$

$=356-444$

- $267-356$

= $178-267$

표 $89-178$

$=0-89$

Temperature

$\left({ }^{\circ} \mathrm{C}\right)$

FIGURE III. RESPONSE SURFACE AND CONTOUR PLOT SHOWING THE EFFECTS OF PRETREATMENT TIME AND TEMPERATURE ON THE TOTAL SUGAR CONTENT WITH INITIAL PH 5.5

Figure 3 show the effects of temperature and time on total sugar content with a $\mathrm{pH}$ of 5.5. The result indicated that this pretreatment should be proceeded for more than 20 min which the total sugar would be increased with a rising of the temperature. The near optimum was obtained 533-622 g/L of total sugar content at $54-60{ }^{\circ} \mathrm{C}$ for $25-30 \mathrm{~min}$.

\section{B. Optimization of Sap Preparation}

Experimental design was planned by RSM using central composite design (CCD) to determine the optimum total sugar concentrations $(\mathrm{Y}, \mathrm{g} / \mathrm{L})$ in the pretreated products. Independent variables were initial $\mathrm{pH}\left(\mathrm{X}_{1}\right)$, temperature $\left(\mathrm{X}_{2},{ }^{\circ} \mathrm{C}\right)$ and time $\left(\mathrm{X}_{3}, \mathrm{~min}\right) .17$ experiments in Table 2 were operated to obtain the optimal condition. The total sugar content could be predicted by (1) which demonstrated that this model conformed to the experiment (Table 2) with 0.942. The maximum total content was $411 \mathrm{~g} / \mathrm{L}$ that can carry out with initial $\mathrm{pH}$ of 4.9 at $54^{\circ} \mathrm{C}$ for $25 \mathrm{~min}$.

$$
\begin{gathered}
\mathrm{Y}=2441.2-326.2 \mathrm{X}_{1}-57.7 \mathrm{X}_{2}-14.5 \mathrm{X}_{3}+25.3 \mathrm{X}_{1}^{2}+ \\
0.4 \mathrm{X}_{2}^{2}-0.2 \mathrm{X}_{3}^{2}+1.8 \mathrm{X}_{1} \mathrm{X}_{2}-3.5 \mathrm{X}_{1} \mathrm{X}_{3}+0.96 \mathrm{X}_{2} \mathrm{X}_{3}
\end{gathered}
$$


TABLE II. OBSERVED ANS PRDICTED RESPONSE OF TOTAL SUGAR AFTER PRETREATMENT

\begin{tabular}{|c|c|c|c|c|c|}
\hline \multirow[t]{2}{*}{ Run } & \multirow[t]{2}{*}{ pH } & \multirow{2}{*}{$\begin{array}{c}\text { Temp. } \\
\left({ }^{\circ} \mathrm{C}\right)\end{array}$} & \multirow{2}{*}{$\begin{array}{l}\text { Time } \\
\text { (min) }\end{array}$} & \multicolumn{2}{|c|}{ Total sugar $(g / L)$} \\
\hline & & & & Observed & Predicted \\
\hline 1 & 5.5 & 30 & 18 & 235 & 210 \\
\hline 2 & 4.9 & 36 & 25 & 195 & 195 \\
\hline 3 & 4.9 & 36 & 10 & 202 & 237 \\
\hline 4 & 6.1 & 36 & 10 & 214 & 218 \\
\hline 5 & 6.1 & 36 & 25 & 111 & 114 \\
\hline 6 & 4.5 & 45 & 18 & 281 & 263 \\
\hline 7 & 5.5 & 45 & 18 & 235 & 211 \\
\hline 8 & 5.5 & 45 & 18 & 204 & 211 \\
\hline 9 & 5.5 & 45 & 18 & 194 & 211 \\
\hline 10 & 6.5 & 45 & 18 & 192 & 209 \\
\hline 11 & 5.5 & 45 & 5 & 159 & 136 \\
\hline 12 & 5.5 & 45 & 30 & 207 & 230 \\
\hline 13 & 4.9 & 54 & 10 & 190 & 188 \\
\hline 14 & 6.1 & 54 & 10 & 207 & 209 \\
\hline 15 & 4.9 & 54 & 25 & 411 & 406 \\
\hline 16 & 6.1 & 54 & 25 & 402 & 365 \\
\hline 17 & 5.5 & 60 & 18 & 369 & 394 \\
\hline
\end{tabular}

The surface and contour plots (Fig 1-3) point the order of the variable affecting sugar preparation as temperature > time $>$ initial $\mathrm{pH}$. To obtain optimal total sugar content, the preparation needed a fair heating temperature and sufficient time with acidic $\mathrm{pH}$ (4.5-4.9).

TABLE III. ANOVA FOR THE FULL QUADRATIC MODEL

\begin{tabular}{cccccc}
\hline Source & (SS) & $(\boldsymbol{M S})$ & $\boldsymbol{F}$ & Probe $>\boldsymbol{F}$ & $\boldsymbol{D f}$ \\
\hline Regression & 104418 & 11602.0 & 12.58 & 0.00151 & 9 \\
Residual & 6457.7 & 922.53 & & & 7 \\
LOF Error & 5568.1 & 1113.6 & & & 5 \\
Pure Error & 889.64 & 444.82 & & & 2 \\
Total & 110875 & & & & 16 \\
\hline
\end{tabular}

Table 3 show analysis of variance (ANOVA) indicated a significant effect of corresponding factors on the response. The model $\mathrm{F}$ value of 12.58 and values of probability $>\mathrm{F}$ indicated that the model terms were significant.

\section{CONCLUSION}

The decomposition of the sugar feedstock by microorganisms could be controlled with a suitable initial $\mathrm{pH}$, warming temperature and time. The preparation of sugar should be adjusted properly before the ethanol fermentation.

\section{ACKNOWLEDGMENT}

This work was financially supported from Prince of Songkla University via Grant no. ENG5805895.

\section{REFERENCES}

[1] M. Germec, I. Turhan, M. Karhan, and A. Demirci, "Ethanol production via repeated-batch fermentation from carob pod extract by using Saccharomyces cerevisiae in biofilm reactor,” Fuel, vol. 161, pp. 304311, 2015.

[2] Z. Luo, L. Wang, and A. Shahbazi, “Optimization of ethanol production from sweet sorghum (Sorghum bicolor) juice using response surface methodology,” Biomass and Bioenergy, vol. 67, pp. 53-59, 2014.

[3] S. Abdullah, Y. Shirai, and E.K. Bahrin, "Fresh oil palm frond juice as a renewable, non-food, non-cellulosic and complete medium for direct bioethanol production,” Industrial Crops and Products, vol. 63, pp. 357361, 2015.

[4] M. Gumienna, A. Szwengiel, A. Szczepanska-Alvarez, K. Szambelan, M. Lasik-Kurdys, Z. Czarnecki, and A. Sitarski, "The impact of sugar beet varieties and cultivation conditions on ethanol productivity," Biomass and Bioenergy, vol. 85, pp. 228-234, 2016.

[5] P. Tamunaidu, N. Matsui, Y. Okimori, and S. Saka, “Nipa (Nypa fruticans) sap as a potential feedstock for ethanol production,” Biomass and Bioenergy, vol. 52, pp. 96-102, 2014.

[6] P. Gupta and K.K. Nayak, "Optimization of keratin/ alginate scaffold using RSM and its characterization for tissue engineering," International journal of Biological Macromolecules, vol. 85, pp. 141149, 2016.

[7] D.M. Santos, A.L. Bukzem, and S.P. Campana-Filho, "Response surface methodology applied to the study of microwave-assisted synthesis of quaternized chitosan," Carbohydrate Polymer, vol. 138, pp. 317-326, 2016.

[8] E.K. Baghkheirati and M.B. Bagherieh-Najjar, "Modeling and optimization of Ag-nanoparticle biosynthesis mediated by walnut green husk extract using response surface methodology,” Materials Letters, vol. 171, pp. 166-170, 2016

[9] M. Dubois, K.A. Gilles, G.K. Atmelton, P.A. Rabers, and F. Smith, "Colorimetric Method for Determination of sugars and Related Substances,” Journal of Analytical Chemistry, vol. 28, pp. 350-356, 1956. 